blood to pass from one auricle to the other. But a very different condition of things obtains during the diastole of the auricles; then, the blood, rushing from the venæ cavæ and the pulmonary veins into the relaxed auricles, might readily find its way through an open foramen ovale, and, under certain conditions, conceivably produce such vibrations as would be represented by murmurs to the ear of the auscultator. How, indeed, can it be asserted with confidence, that, in those cases of open foramen ovale associated with other defective conditions of the heart, in which murmurs were heard during life,-how can it be asserted, that none of the murmurs ever arose at the open foramen? Why is it assumed that they always take their origin in those other defective conditions, whatever they be, of the heart?

In the present case, the anatomical condition of the aperture of the foramen was plainly most favourable for the production of vibrations, viz., $a$ thin membranous band stretched across the opening, and attached only at its two extremities. A current of blood rushing through such an aperture, from the right to the left auricle (and we have seen that the current could not pass from left to right) would hardly fail to throw the membrane into a vibratile state. Any impediment to the passage of the blood through the lungs, and consequently through the right side of the heart, would naturally tend to in. crease the flow of blood through the foramen ovale, by obstructing its realy exit from the right auricle into the right ventricle. In this case, we must suppose that the tubercular condition of the luug impeded the circulation, and so might have increased the intensily of the bruit, as it was last heard during the life of the patient.

Again, it has been objected that the forco of the blood flowing into the auricle from the venæ cavæ is not sufficient to give rise under such circumstances to a bruit. To this I will answer, that great force in a current is not always necessary to produce a bruit, and that under a favourable combination of things a weak current may occasion a very loud murmur. Let me call to mind: a prolonged loud and thrilling diastolic mitral murmur; the roaring bruit, which is so often heard in the necks of anæmic girls, produced by the least pressure of the stethoscope on the cervical veins. Even over the radial artery of anæmic persons I have on two occasions heard a bruit which, if heard over the cardiac region, would have been called a loud blowing murmur. If such currents of blood give occasion to such murmurs, why not one resulting from the rush of blood from the venr cavæ-the venous trunks of the body-into the right auricle, and then through the open foramen ovale.

For such reasons, I think the objections to the probability of the bruit being in this case formed at the foramen ovale untenable. One argument in favour of the view I hold I bave not vet mentioned, though $I$ think it a very powerful one; it is this: If the bruit was not formed at the foramen ovale, what produced it? I certainly think it much more rational to believe, that a long and loud bruit, such as this, heard on several separate occasions (and most carefully observed) at a peculiar part of the thorax in front, and loudly also in the interscapular region, arose at the open foramen, than to acquiesce in the proposition that some inexplicable mystery invlves the subject. I have given, I think, fair reasons why, ì priori, there is nothing improbable in the existence of such a murmur; and the facts, as here related, appear to me to justify the conclusion, that a murmur so produced really did exist in the present case.

Another fact of considerable interest was observed in connection with the lungs. I have stated that, seventeen hours before death, a careful examination detected no alteration what ever from the healthy state at any part of the chest, either in the percussion or auscultation sounds of the lungs; and that, nevertheless, there was found, after death, no portion of either lungs in which were not thickly strewn miliary tubercles. The fact that tubercular matter may be deposited, under certain conditions, in the pulmonary tissues, and yet produce no alterations in the physical signs, such at least as our senses can detect, has long been almitted by our best auscultators but it is one which we have not frequently an opportunity of positively demonstrating, and I venture to thirk has been of late somewhat overlooked. There are writers, for example, who speak of a pretubercular stage of phthisis; but how do they prove the non-existence of tubercle in the lungs in such cases? Evidently they can only do so by forming their judg ment on the absence of those physical signs, which indicate the presence of foreign matters in the pulmonary tissue. How fallacious such a mode of judging is, seems proved by this case.
The absence of morbid physical signs is no proof of the absence of tubercle in the lungs; and therefore to speak of a pre-tubercular stage of phthisis (or indeed of pulmonary phthisis at all, apart from the presence of a tangible materies morbi in the lungs) appears an abuse of language, unwarranted by true observation or by fair hypothesis. Let me put the case in another form. Would the warmest supporters of pretubercular stages of phthisis venture to call that a case of tubercular disease of the lungs, in which, however strongly marked during life had been the signs of their (so-called) pretubercular condition, no tubercle could be found after death ? In this respect, and as demonstrating the difficulties which beset the auscultator, I venture to think this case well worthy of record.

The reasons why physical signs of disease are absent in cases of this nature are, I think, plain. Skoda says: "There are no distinct signs by which we can with certainty diagnose the existence of acute miliary tubercles; we can only surmise their existence. Solitary tubercles do not of themselves produce the slightest change in the percussion-sound of the lungs even though they be scattered through these organs in very considerable quantity." In this case healthy air-containing. tissue intervened between the tubercles; and so na alteration occurred in the percussion-sound. The respiratory: murmur. was clear and loud; because the air entered freely into all parts of the lungs. There were no râles; because there was no inflammatory exudation; indeed, the tissues when cut across were, comparatively speaking, remarkably dry.

The pathological specimens on which the above remarks are founded, excited some discussion at the Pathological Society, and I have therefore detailed the case at length. It appears to illustrate a new fact in relation to the origin of cardiac bruits ; and to demonstrate a point of great practical significance in the diagnosis of pulmonary disease. In another respect the case is instructive, and exemplifies a well-repeated apopthegm(too rarely illustrated practically) viz., that our errors are sometimes full of instruction. I know not whether some exceedingly cunning observer might not have escaped the complete error of diagnosis into which $I$ fell; but of this $I$ am sure, that the majority of us would have infallibly agreed with me at the moment in the false diagnosis, had they seen and heard the symptoms and signs as I saw and heard them. At all events, if the views I have taken regarding the origin of the cardiac bruit be correct-and I do not see on what grounds they can be disputed-it is certain that there is established by this case the existence of a source and mode of origin of a cardlac bruit, as yet neither recognised nor admitted in the history of the physical diagnosis of the abnormal sounds of the heart.

\section{ON THE LOCAL ENCOURAGEMENT OF SCIENCE BY THE STATE.}

By Henry W. Ruarsey, Esq., Cheltenham.

As important question has been mooted at the two last anniversaries of the British Association for the Advancement of Science, namely, "Whether any measures could be adopted by the Government or Parliament that would improve the position of science and its cultivators?"

Before offering any suggestions of my own, I wish to express my unqualified assent to the principal propositions which have been already made by eminent persons, and which are embodied in the printed reports of that association; such as-the institution and liberal endowment of professorships of physical science, where these do not exist in sufficient number and variety, at our universities; the encouragement of the study of physical science by the foundation of scholarships, fellowships, and other similar rewards for proficiency therein; the localization and accommodation of various learned and scientific societies at the cost of the mation, in an appropriate building in the metropolis; and the constitution of a central board of science, composed partly of persous holding offices under the Crown, and partly of men of the highest distinction in science, to whom the Government might refer for aid and advice in the application of national funds, and in the public execution of projects for the promotion of science.

But the object of the following suggestions is to endeavour to show tbat the Government and Parliament might, with equal reason, be called upon to establish and maintain, in every district of the kingdom, an organised system of scientific investigation and statistical record in the various departments of 
natural science,-those especially which bear obviously and practically upon the moral and physical welfare of the masses of society.

At the last meeting of the British Association, Lord Stanley, in his excellent address to the section of Economic Science and Statistics, clearly laid down the principle, that the collection of statistics in all departments is essentially an affair of Government. In this opinion, I most fully concur. Private labourers in the field of statistical research, however earnest, influential, and intelligent, are generally deterred from a continuous prosecution of their investigations, partly by the great expense attending upon casual and isolated efforts, and partly by impediments and objections frequently raised against what has been called " the meddling of unauthorised individuals".

I have elsewhere remarked upon certain defects in our national records of vital statistics, owing to-1, the want of accurate verification of original facts ; 2 , the want of properlydefined spheres for their collection and compilation; and 3 , the neglect or omission of numerous particulars, which could be ascertained only by means of a national system of inquiry.

Our social statistics, for analogous reasons, are strikingly defective. Here the information obtained is still more dependent upon the particular views of local observers and reporters, and is therefore less reliable.

The collection of agricultural statistics also remains an unsolved problem; and will, probably, never be properly or satis. factorily performed, unless under scientific direction, connected with other objects of public utility, and divested of its merely fiscal aspect.

Thus, in the first place, a thorough physiological knowledge of the fauna and flora of any district would be an essential qualification for a Superintending Local Reporter, who ought to be competent to inquire into the occurrence of unusual or morbid conditions of any tribes or species of the vegetable kingdom; to note occasional developments, in air and water, of peculiar forms of insect or animalcular life; to investigate the nature of these phenomena, their connexions, and their influence upon vital or functional changes in the higher order of animals, and in man himself. The same officer would naturally be the chief registrar and compiler of meteorological and cos mical phenomena-a field of inquiry which is vastly increasing in extent and interest as regards the practical concerns of life, yet (if we except what is so well done at the Royal Observatory, and by the Meteorological Department of the Board of Trade) cultivated only in localities favoured by the casual residence of philosophical amateurs.

Some such local officer should also be competent to direct geological researches, with reference to social objects; as agriculture, drainage, water supply, building, etc.

Again, in the application of chemistry to local purposes, whether educational or practical, great necessity exists for highly scientific agents in official position. To determine the composition and qualities of different soils and waters in changing seasons and circumstances; to analyse manures and crops; to indicate the comparative advantages, test the purity, and detect the falsitications of articles sold or used for food and beverage; to ascertain the genuineness of medicines, and to reveal the presence of any poisonous or deleterious agents which may exist in manufactured articles or organic structures;-all these are indispensable duties for a highly qualified public ana lyst and histologist, who should be responsible, not so much to the inhabitants of the locality-i. $e$., to its producers, manufac turers, and retail dealers-as to the nation in its collective capacity.

Here, then, Govermment may fairly step in to the aid of science on grounds of public safety. It would be easy to show how such an officer would be the most availatle and competent referee in those forensic inquiries which affect human life, health, and liberty, and which, as they are now prosecuted in this country, serve little more than to bring physical science into contempt, and its adepts into disrepute.

An independent public officer, of high scientific attainments, could alone be relied upon for accurate and trustworthy reports on the effects of various industrial occupations and commercial processes which are suspected to be injurious to the commurity, or to persons employed in them, especially in crowded populations. The same officer would naturally be the scientific ad. viser and assessor of local executive boards;* as the Kreisphysicus (a physicist rather than a physician) of the German States is to their provincial and district magistrates. An officer

* "As assessors or advisers to executive boards, the services of scientific men would be highly valuable." (Glasgow Report of British Association, Parliamentary Committee, p.lvi, 1855.) of this kind might also act as instructor of the people in matters which connect science with daily life and labour. The public chemical laboratory, with philosophical apparatus and mechanical or industrial models-for there should be such an institute in every district-should be open, under his superintendence, not only for the gratuitous instruction of the people, but for their personal protection, by affording them, also gratuitously, the means of detecting adulteration or decay in articles of daily use and consumption.

The regular statistical reports-which, as I have suggested, might be compiled by some such scientific officer-exhibiting the fluctuations of vital force in man, animals, and plants, under varying physical or climatic conditions, and in connexion with local customs, habits, and arrangements, should be printed and circulated for municipal and popular information in every district. All this could be done without fear, favour, or prejudice, only in so far as the required scientific agents be made independent of disturbing local influences. They should be " emancipated from all such interference as is calculated to obstruct the zealous performance of their duties" (See Glasgow Report, supra cit., p. Ixii, 1855).

The size and extent of the district in which such a professor or officer might act with advantage to the public, is a correlative question, which I have already discussed both in my Essays on State Medicine, and in my paper On the Territorial Distribution of the Population, read before Section $\mathrm{F}$ of the British Association, at its last meeting.

I do not say that in every district, of the extent suggested in that paper, one such scientific person would suffice as the sole authority; that is, as teacher, referee, inquirer, and reporter. On the contrary, I think it probable that the fnnctions of the professor might often be advantageously separated from those of the investigator; and therefore that, in some places, two specially qualified person might be very judiciously appointed. It is also probable that certain technical inquiries might sometimes require a further, though perhaps temporary, division of labour. The civil engineer and the analytical chemist are of equal importance in public undertakings.

Moreover, a sufficient knowledge of physiology, as regards living forms generally, - of pathology, in the same wide signification,- - of chemistry, theoretical and practical,- of geology,- - of meteorology,-and of statistical processes and results, - might not always coexist in the same officer. But a general acquaintance with the natural sciences, official aptitude, power to call in technical aid, or to refer any disputed point to a metropolitan board, and liberty to accept the local co-operation of philanthropic persons more profoundly versed in specialities, are conditions which would render one scientific appointment (beside that of a local professor) more beneficial to the public than the creation, in the same place, of several scientific posts, which, from the very circumstance of their number, would of necessity be inadequately endowed.

The scientific offices should be "placed on a level, in respect to salary, with such other civil appointments as are an object of ambition to highly educated men." (See Glasgow Report, loc. cit.) By a national provision of this kind, inducements would be held out to students to acquire a knowledge of scientific truths; " and, after the period of pupilage has expired, to extend it, and turn it to useful account;" while "the whole body of competent men of science" would exert "a due influence over the determination of practical questions, dependent for their correct solution on an accurate knowledge of scientific principles." (Ibid., p. xlviii.)

With regard to the power of appointment, we may be sure that extremely few local executive boards, as at present constituted, would be likely to select scientific agents of the highest qualifications; nor could such a right be fairly claimed by dis trict authorities, if the cost were borne by the nation. No existing board would be so capable of determining these appointments as the "Board of Science", suggested in the Glasgono Report of the Parliamentary Committee of the British Association; although the recommendations of those local residents who are competent to form an opinion would of course have their due weight.

It is difficult to conceive a limit to the benefits which science, thus established and supported, might confer on the people. It would be difficult, I think, to point out any direction in which the state, by legislative sanction, could more materially aid the cultivation of science, than by connecting it with the improved administration of what we call " local self-government", and by enlisting it in the cause of a correct compilation of national and local statistics. 